\title{
Relationship of Insulin Binding and Insulin-stimulated Tyrosine Kinase Activity Is Altered in Type II Diabetes
}

Richard J. Comi, George Grunberger, and Phillip Gorden

Diabetes Branch, National Institute of Arthritis, Diabetes, Digestive and Kidney Diseases, National Institutes of Health, Bethesda, Maryland 20205

\begin{abstract}
The insulin receptor contains an $\alpha$ subunit with insulin binding properties and a $\beta$ subunit with insulin-stimulated tyrosine kinase function. Preparations containing insulin and insulinlike growth factor I (IGF-1) receptors were obtained from solubilized human red cell membranes by affinity chromatography. After separate assays for insulin binding and insulin-stimulated tyrosine kinase activities, a high degree of correlation was found between these activities in preparations from normals and diabetics. Identical studies using IGF-1 as the ligand showed a lesser degree of correlation. We compared 24 normal subjects and 14 untreated type II diabetics and found significant diminution in the slope of the line coupling insulin binding and insulin-stimulated kinase activities in the diabetics. This difference was not observed in a similar study of IGF-1-related activities. Compared to normal controls, untreated type II diabetics have reduced tyrosine kinase activity stimulated per unit insulin binding.
\end{abstract}

\section{Introduction}

The detailed mechanism by which insulin binding to its receptor results in the various biologic actions of insulin is unknown. The insulin receptor, composed of two subunits, is believed to contain the necessary information to signal the initiation of these events; insulin binding "activates" this signal (1). The $\alpha$ subunit contains the major insulin binding region of the receptor, and the proposed cDNA sequence for this subunit suggests that it is totally extracellular $(2,3)$. The $\beta$ subunit contains a tyrosinespecific protein kinase (4) and is autophosphorylated; this subunit is a transmembrane protein $(2,3,5)$. Interest in the insulin receptor has focused on the kinase function of the $\beta$ subunit, either as the means for coupling insulin binding to insulin-induced effects or as a parallel manifestation of the coupling process. Under these circumstances it may relate to only a limited number of effects.

Studies of insulin receptors isolated from circulating cells of patients with extreme insulin resistance have revealed dissociations in the binding ( $\alpha$ subunit) and the protein kinase ( $\beta$ subunits). Grunberger et al. described a markedly reduced tyrosine kinase activity in lectin-purified monocyte insulin receptors, despite the presence of normal insulin binding, in monocytes from such a patient (6). Grigorescu et al. reported a similar finding

Portions of this work were presented in abstract form of 3 May 1986 at the national meeting of the American Society for Clinical Investigation in Washington, DC.

Received for publication 13 August 1985 and in revised form 24 September 1986.

The Journal of Clinical Investigation, Inc.

Volume 79, February 1987, 453-462 with solubilized red cell ghost insulin receptors in a different patient with near-normal red cell insulin binding (7).

Up until now, clinical studies of the $\beta$ subunit of the insulin receptor have been largely restricted to these unusual patients with extreme forms of insulin resistance. This is due in part to methodologic problems in studying patients with possibly more subtle defects. We have developed an assay system to permit the semiquantitative study of the activities of each of the subunits of the insulin receptor isolated from red blood cells. This system allows facile comparison of different patient groups. We have chosen the erythrocyte for study because of the large number of insulin receptors obtainable from modest amounts of blood and have used lectin affinity purification and concentration of these receptors to facilitate study of the receptors. Using these methods, we observed an alteration in the relationship of insulin binding and insulin-stimulated tyrosine kinase activity in preparations from type II diabetics compared with normal subjects. Untreated type II diabetics show a significant reduction in the rate of tyrosine kinase activity stimulated by insulin per unit insulin binding activity when compared with normal controls.

\section{Methods}

Material. All reagents were of standard laboratory grade. The following reagents were purchased for these studies: Ficoll-Hypaque (Pharmacia Fine Chemicals, Piscataway, NJ), lectin-agarose beads (E. Y. Laboratories, Inc., San Mateo, CA), wheat germ agarose beads (Miles-Yeda, Rehovot, Israel), porcine insulin (Elanco, Indianapolis, IN), monoiodinated A-14 receptor grade porcine ${ }^{125} \mathrm{I}$-insulin and $\left[{ }^{32}\right.$-P] adenosine triphosphate (New England Nuclear, Boston, MA), aprotinin (Boehringer Mannheim Biochemicals, Indianapolis, IN) and Triton X-100 (New England Nuclear). The following reagents were obtained from Sigma Chemical Company, St. Louis, MO: lactose, $N$-acetylglucosamine, $\alpha$-mannose-mannoside, fucose, phenylmethylsulfonyl fluoride (PMSF), cytosine triphosphate (CTP), ${ }^{1} \mathrm{ATP}, \mathrm{Hepes}$, poly $\left(\mathrm{GluNa}^{80} \mathrm{Tyr}^{20}\right.$ ) (polyGT), polyethylene glycol $(3,000-5,000 \mathrm{~mol} \mathrm{wt})$, and bacitracin. Proinsulin was the gift of B. Frank (Eli Lilly \& Co., Indianapolis, IN) and chicken insulin was provided by the National Hormone and Pituitary Agency, Baltimore, MD. Unlabeled insulin growth factor I (IGF-1) was obtained from AmGen Biologicals, Thousand Oaks, CA, and ${ }^{125}$ I-IGF-1 was obtained from Amersham Corp., Arlington Heights, IL. All other reagents were of laboratory grade.

Patients and controls. All subjects were patients or volunteers at the National Institutes of Health Clinical Center, and signed consent was obtained. Baseline fasting glucose, insulin, glycosylated hemoglobin, hematocrit, and reticulocyte counts were performed at the time of study (Table I). A total of 24 normal volunteers without history of diabetes or glucose intolerance were studied ( 18 males and 6 females, ages 20-56). In addition, five obese individuals ( $>150 \%$ of ideal body weight) with normal oral glucose tolerance tests (2-h postprandial glucose $<180 \mathrm{mg}$ / $\mathrm{dl}$ in all cases) were studied. 14 type II diabetics, diagnosed on the basis of history, fasting blood glucose (>140 mg/dl), glycosylated hemoglobin

1. Abbreviations used in this paper: $\mathrm{B} / \mathrm{F}$, bound over free; CTP, cytosine triphosphate; PEG, polyethylene glycol; polyGT, poly $\left(\mathrm{GluNa}^{80} \mathrm{Tyr}^{20}\right)$. 
Table I. Clinical Characteristics

\begin{tabular}{|c|c|c|c|c|c|c|c|c|c|}
\hline Subjects & $n$ & M:F & Age & Weight & FBS & HAlc & Insulin & Hct & $\begin{array}{l}\text { Reticulocyte } \\
\text { count }\end{array}$ \\
\hline & & & $y r$ & $k g$ & $g / d l$ & $\%$ & $\mu U / m l$ & $\%$ & $\%$ \\
\hline Control & 24 & $18: 6$ & $\begin{array}{l}29.0 \pm 8 \\
(24-56)\end{array}$ & $\begin{array}{l}73.0 \pm 14.2 \\
(56-115)\end{array}$ & $\begin{array}{c}83.9 \pm 8.2 \\
(67-99)\end{array}$ & $7.5 \pm 1.0$ & $<10$ & $\begin{array}{l}43.5 \pm 3.0 \\
(34-50)\end{array}$ & $\begin{array}{l}0.90 \pm 0.27 \\
(0.4-1.1)\end{array}$ \\
\hline $\begin{array}{l}\text { Type II } \\
\text { Diabetics }\end{array}$ & 14 & $8: 6$ & $\begin{array}{l}46.7 \pm 9.1 \\
(26-65)\end{array}$ & $\begin{array}{l}93.6 \pm 15.5 \\
(72-118)\end{array}$ & $\begin{array}{l}194.2 \pm 66 \\
(140-363)\end{array}$ & $\begin{array}{l}11.3 \pm 1.6 \\
(9.6-14.8)\end{array}$ & $\begin{array}{l}12.4 \pm 1.6 \\
(4-18)\end{array}$ & $\begin{array}{l}44.4 \pm 3.5 \\
(37-48)\end{array}$ & $\begin{array}{l}1.16 \pm 0.5 \\
(0.4-2.3)\end{array}$ \\
\hline $\begin{array}{l}\text { Obese } \\
\text { Controls }\end{array}$ & 5 & $2: 3$ & $\begin{array}{l}40.8 \pm 10.5 \\
(31-61)\end{array}$ & $\begin{array}{c}129 \pm 44 \\
(72-212)\end{array}$ & $\begin{array}{c}86.8 \pm 9.1 \\
(70-95)\end{array}$ & $\begin{array}{r}7.3 \pm 0.5 \\
(6.7-8.3)\end{array}$ & - & $42.1 \pm 4.9$ & $0.9 \pm 0.25$ \\
\hline
\end{tabular}

( $>10 \%$, normal $<8.8 \%$ ), were studied (eight males and six females, ages 35-56). All patients were either untreated or taken off sulfonylurea therapy with consent for 7-10 d. The data for all subjects are shown in Table I.

Preparation of solubilized red blood cell membranes. Red blood cell ghosts were prepared as described by Grigorescu et al. (8) with the following modifications. Samples of $100 \mathrm{ml}$ of blood were drawn into heparinized tubes and diluted 1:2 with normal saline. The diluted blood was layered over Ficoll-Hypaque gradients and centrifuged at $1,000 \mathrm{~g}$ for 35 min at room temperature or $10 \mathrm{~min}$ at $4^{\circ} \mathrm{C}$. The monocyte layer and plasma were aspirated away from the red cell pellet, which was resuspended in normal saline and recentrifuged over Ficoll-Hypaque at $4^{\circ} \mathrm{C}$ for $10 \mathrm{~min}$ at $1,000 \mathrm{~g}$. The supernatant was discarded and $5 \mathrm{ml}$ of the red cell pellet were withdrawn for intact red cell insulin binding. Microscopic examination of these aliquots showed absence of white cell contamination. The remaining red cell pellet $(\sim 45 \mathrm{ml})$ was suspended in $400 \mathrm{ml}$ of $5 \mathrm{mM}$ Tris phosphate buffer at pH 8 containing $1 \mu \mathrm{M}$ PMSF and $1 \mu \mathrm{g} / \mathrm{ml}$ of aprotinin at $4^{\circ} \mathrm{C}$ for $1 \mathrm{~h}$. The ghosts were then pelleted at $35,000 \mathrm{~g}$ for $20 \mathrm{~min}$ at $4^{\circ} \mathrm{C}$, resuspended in $0.5 \mathrm{mM}$ Tris phosphate buffer containing the same enzyme inhibitors and washed repeatedly by recentrifugation and resuspension until the supernatant was colorless.

The membrane pellet was washed with $50 \mathrm{mM}$ Hepes containing 1 $\mu \mathrm{M}$ PMSF and $1 \mu \mathrm{g} / \mathrm{ml}$ of aprotinin and then solubilized in a total volume of $15 \mathrm{ml}$ of the same buffer containing $1 \%$ Triton X-100 for $1 \mathrm{~h}$ at $4^{\circ} \mathrm{C}$. The solubilized material was then centrifuged at $180,000 \mathrm{~g}$ for $90 \mathrm{~min}$ at $4^{\circ} \mathrm{C}$ to obtain a clear supernatant containing the solubilized membrane proteins.

Lectin purification. We tested several agarose-fixed lectins for their ability to reversibly bind the solubilized red blood cell insulin receptors and concentrate them. Red blood cell membranes solubilized in $1 \%$ Triton $\mathrm{X}-100$ were divided into equal aliquots and passed twice over 1-ml columns of agarose-bound lectins prepared according to Hedo (9). The flow-through was collected. The columns were washed with 40 column volumes of $150 \mathrm{mM} \mathrm{NaCl}, 50 \mathrm{mM}$ Hepes and $0.1 \%$ Triton X-100. The glycoproteins were eluted with the same buffer containing the specific sugar for the lectin in the column (see Table II). The carbohydrate eluates were compared with the original solutions and the flow-through for insulin binding per $40 \mu \mathrm{l}$ of material as described under Binding Studies. The lectins studied, the elution sugar solutions, and the results of the binding studies are shown in Table II. From these experiments, ricin II was chosen as the lectin for partial purification and concentration of the red blood cell insulin receptors.

2-ml columns of ricin II attached to agarose beads were used for all samples. These columns demonstrated consistent extraction of $60-80 \%$ of the specific insulin-binding activity per $80 \mu \mathrm{l}$ found in the solubilized red blood cell membrane preparations as assessed by comparison with flow-through binding. The ricin II columns also showed a consistent ability to concentrate insulin-binding activity per unit volume over that found in solubilized erythrocyte ghost preparations. During the preparative use of the columns, $2-\mathrm{ml}$ fractions of the $0.1 \mathrm{M}$ lactose eluate were collected. The peak of binding activity per $80 \mu \mathrm{l}$ usually appeared in fraction 3 . The fractions were collected, assayed for specific ${ }^{125}$ I-insulin binding, and the fraction containing the greatest amount of binding activity was used for the tyrosine kinase assay.

Binding studies of whole red blood cells. Insulin binding to intact red blood cells was performed according to the procedure of Ghambir et al. (10). In brief, red blood cells purified over consecutive Ficoll-Hypaque gradients were washed one time in buffer $\mathrm{G}$ and incubated at $15^{\circ} \mathrm{C}$ for 90 min with varying concentrations of unlabeled insulin $(0-100,000 \mathrm{ng} /$ $\mathrm{ml}$ ) and $0.1 \mathrm{ng} / \mathrm{ml}$ of ${ }^{125} \mathrm{I}$-insulin $(10,000 \mathrm{cpm})$. All data were expressed as bound insulin/free insulin per $4.5 \times 10^{9}$ cells.

Binding studies of solubilized and lectin-purified preparations. Insulin binding to all solubilized membrane preparations was performed as previously described (11). 80- $\mu \mathrm{l}$ aliquots of the solubilized membranes or lectin-purified preparations were incubated at $4^{\circ} \mathrm{C}$ for $24 \mathrm{~h}$ in buffer adjusted to $0.4 \%$ Triton $\mathrm{X}-100$ and containing $150 \mathrm{mM} \mathrm{NaCl}, 50 \mathrm{mM}$ Hepes, $1 \mu \mathrm{M}$ PMSF, $0.1 \mathrm{ng} / \mathrm{ml}$ of ${ }^{125} \mathrm{I}$-labeled insulin (10,000 cpm), and varying concentrations of insulin $(0-10,000 \mathrm{ng} / \mathrm{ml})$ in a total volume of $200 \mu \mathrm{l}$. Bound insulin was separated from free insulin with $12.5 \%$ final concentration of polyethylene glycol (PEG) and the pellet was washed one time with PEG before counting. The specific insulin-binding activity

Table II. Assay of Lectin Affinity for Soluble Erythrocyte Insulin Receptors

\begin{tabular}{|c|c|c|c|}
\hline \multirow[b]{2}{*}{$\begin{array}{l}\text { Lectin attached to } \\
\text { agarose beads }\end{array}$} & \multirow[b]{2}{*}{$\begin{array}{l}\text { Carbohydrate and concentration } \\
\text { for elution }\end{array}$} & \multicolumn{2}{|c|}{$\begin{array}{l}\text { Percent of specific } \\
\text { insulin binding of } \\
\text { initial solubilized } \\
\text { erythrocyte ghosts }\end{array}$} \\
\hline & & $\begin{array}{l}\text { Flow- } \\
\text { through }\end{array}$ & Eluate \\
\hline & & $\%$ & $\%$ \\
\hline Ricin I & 0.1 M Lactose & 54 & 50 \\
\hline Ricin II & $0.1 \mathrm{M}$ Lactose & 20 & 70 \\
\hline $\begin{array}{l}\text { Wheat germ } \\
\text { agglutinin }\end{array}$ & $0.3 \mathrm{M} \mathrm{N}$-acetylglucosamine & 60 & 20 \\
\hline Dolichos biflorus & $0.3 \mathrm{M} N$-acetylglucosamine & 96 & 0 \\
\hline Soybean & $0.3 \mathrm{M}$ Galactose & 60 & 0 \\
\hline $\begin{array}{l}\text { Soybean } \\
\text { japonica }\end{array}$ & $0.2 \mathrm{M}$ Galactose & 100 & 0 \\
\hline Lotus & $\begin{array}{l}\text { 0.1 M Alpha-methyl- } \\
\text { mannopyranoside }\end{array}$ & 33 & 33 \\
\hline Concanavalin A & $\begin{array}{l}\text { 0.1 M Alpha-methyl- } \\
\text { mannopyranoside }\end{array}$ & 92 & 11 \\
\hline Pea & $\begin{array}{l}\text { 0.1 M Alpha-methyl- } \\
\text { mannopyranoside }\end{array}$ & 70 & 2 \\
\hline Lentil & $\begin{array}{c}\text { 0.1 M Alpha-methyl- } \\
\text { mannopyranoside }\end{array}$ & 96 & 0 \\
\hline
\end{tabular}


of a preparation was defined as the total binding minus its binding in the presence of $10,000 \mathrm{ng} / \mathrm{ml}$ of unlabeled insulin. Degradation in these binding assays was assessed by determining the percent of unbound radioactivity soluble in $10 \%$ trichloroacetic acid. Degradation was always $<7 \%$ in the lectin-purified preparations, $<10 \%$ in the solubilized membrane preparations, and often $>10 \%$ in the flow-through from the ricin II columns despite the presence of PMSF. All assays were performed in duplicate and repeated for confirmation.

IGF-1 binding studies were performed in an identical fashion, using ${ }^{125} \mathrm{I}-\mathrm{IGF}-1(10,000 \mathrm{cpm}, 0.1 \mathrm{ng} / \mathrm{ml})$ and varying concentrations $(0-10,000$ $\mathrm{ng} / \mathrm{ml})$ of unlabeled IGF-1. Heterologous ligand competition curves $\left({ }^{125} \mathrm{I}-\right.$ insulin competed by unlabeled IGF-1 and ${ }^{125}$ I-IGF-1 competed by unlabeled insulin) were also performed.

Autophosphorylation of the insulin receptor. The ability of the insulin receptor to phosphorylate its own $\beta$ subunit was tested as described previously (12). 250- $\mu$ l aliquots of solubilized membrane or ricin II-purified preparations were used, and immunoprecipitation of the labeled insulin receptor was carried out with human anti-insulin receptor antibody.

Artificial substrate assay of the tyrosine kinase activity of the insulin receptor. Appropriate conditions for assaying the tyrosine kinase activity of ricin II-purified erythrocyte membrane preparations were determined with the method of Grunberger et al. (13). These experiments were performed with the artificial substrate polyGT. $20 \mu \mathrm{l}$ of preparation was incubated with or without insulin in a total volume of $30 \mu l$ in $50 \mathrm{mM}$ Hepes at room temperature. The artificial substrate, polyGT, was then added to a final concentration of $2.5 \mathrm{mg} / \mathrm{ml}$, along with $\mathrm{MgCl}_{2}, \mathrm{ATP}$ $\left(100 \mu \mathrm{M}\right.$ final) and $\gamma{ }^{32} \mathrm{P}$ ATP $(0.5 \mu \mathrm{M}$ final $)$ in a total volume of 80 $\mu \mathrm{l}$. The reaction was stopped by spotting $60 \mu \mathrm{l}$ of reaction mixture on $2-\mathrm{cm}$ squares of filter paper and immersing the papers in $10 \%$ trichloroacetic acid containing $10 \mathrm{mM}$ sodium pyrophosphate. All assays were done in duplicate and repeated a second time for verification. Studies for IGF-1 stimulation of tyrosine kinase activity were performed in a similar fashion.

Tyrosine kinase activity was linear over at least $30 \mathrm{~min}$ (usually to $90 \mathrm{~min}$ ), required $30 \mathrm{~min}$ of preincubation with insulin at room temperature and $20 \mathrm{mM} \mathrm{Mg}^{2+}$ for full activation of the activity, and had a maximal response to $10^{-6} \mathrm{M}$ insulin (Fig. 1) and $10^{-8} \mathrm{M}$ IGF-1. Addition of excess unlabeled ATP after 15 min of reaction to stop incorporation of ${ }^{32} \mathrm{P}$ into the artificial substrate was followed by loss of $15-25 \%$ of the label over the ensuing $15 \mathrm{~min}$ (data not shown) with no difference between preparations from normal or diabetic subjects. Addition of 50-100 mM vanadate into the reaction mixture produced no effect (data not shown) on the tyrosine kinase activity of preparations from normal or type II diabetic subjects. Preincubation of labeled insulin with the lectin-purified preparations for $30 \mathrm{~min}$ at room temperature and followed by addition of trichloroacetic acid (final concentration $10 \%$ ) resulted in recovery of $>90 \%$ of the label in the precipitate from both normal and diabetic preparations. The addition of $100 \mu \mathrm{M}$ CTP to the reaction mixtures for normals or diabetics had no consistent effect upon kinase activity nor a different effect between the two types of preparations. There was no measurable ATPase activity in the ricin II-purified preparations.

These studies were used to select assay conditions (30-min room temperature preincubation with insulin, $200 \mathrm{mM} \mathrm{MgCl}$ [final], and 15 min reaction time) for determination of tyrosine kinase activity. All studies were performed with $10^{-7} \mathrm{M}$ insulin rather than $10^{-6} \mathrm{M}$ to allow comparison with other studies using monocytes and fibroblasts in our laboratory. Tyrosine kinase activity of the insulin receptor is expressed as picomoles of phosphate incorporated in $15 \mathrm{~min}$ per milligram of polyGT per $20 \mu \mathrm{l}$ of preparations. Stimulated tyrosine kinase activity is the difference between the activity of a preparation in the presence and absence of the stimulating ligand.

$I G F-1$ studies. 10 preparations from the normal subjects and seven preparations from the diabetic patients were subjected to binding and kinase assays with biosynthetic IGF-1 as ligand. The dose response curve for IGF-1 stimulation of phosphorylation of polyGT showed a maximal response at $10^{-8} \mathrm{M}$ IGF-1 under identical conditions to those used for insulin.

Insulin at $10^{-7} \mathrm{M}$ and IGF-1 at $10^{-8} \mathrm{M}$ were not additive in their

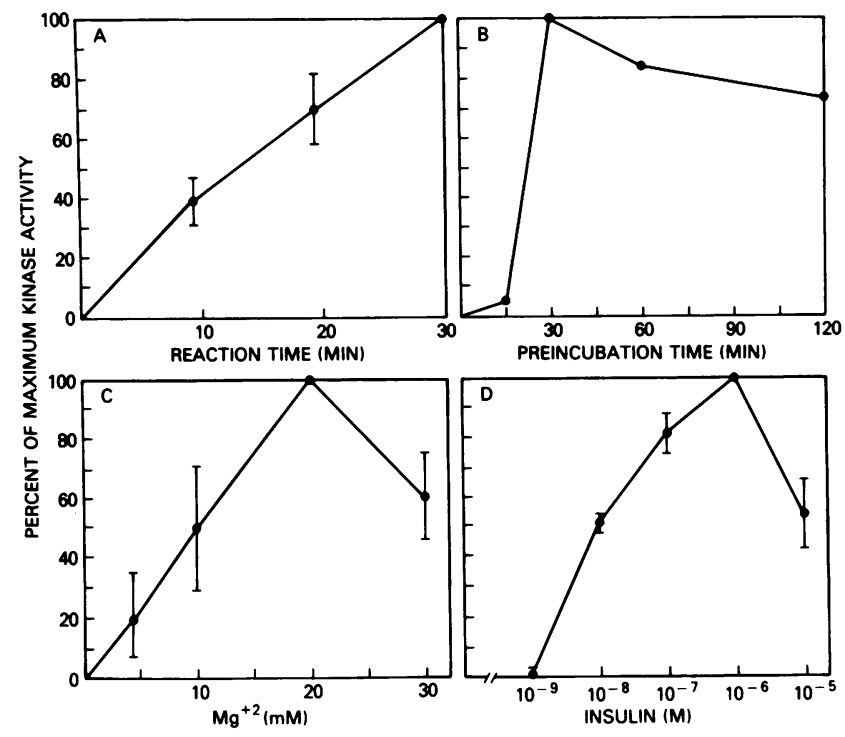

Figure 1. Standardization of conditions for assaying tyrosine kinase activity of ricin II-purified erythrocyte preparations with polyGT. The ordinate in each panel is the percent of maximum tyrosine kinase activity in picomoles ${ }^{32} \mathrm{P}$ per milligram polyGT. Standard deviations are shown. Tyrosine kinase activity is a linear function of time at room temperature for at least $30 \mathrm{~min}(A)$, with maximum activity of the receptor attained after $30 \mathrm{~min}$ of preincubation with insulin at room temperature $(B)$. Tyrosine kinase activity is maximal with $20 \mathrm{mM}$ $\mathrm{MgCl}_{2}$ present $(C)$ and a concentration of $10^{-6} \mathrm{M}$ insulin $(D) .10^{-7} \mathrm{M}$ insulin stimulated $80-90 \%$ of the total activity.

ability to stimulate phosphorylation of polyGT under these assay conditions (data not shown).

Binding and kinase studies under identical conditions. Five preparations from normal individuals and five from untreated type II diabetics were studied in both binding and kinase assays under identical buffer and temperature conditions. The buffer contained $150 \mathrm{mM} \mathrm{NaCl}, 50$ $\mathrm{mM}$ Hepes, $0.1 \%$ Triton X-100, $10 \mathrm{mM}$ bacitracin, and $1 \mu \mathrm{g} / \mathrm{ml}$ of aprotinin. Equilibrium binding of insulin was attained in this buffer in $3 \mathrm{~h}$ at room temperature, with $<10 \%$ degradation of labeled insulin. Kinase and binding assays were performed as described above after simultaneous 3-h incubation with insulin at room temperature to assess insulin dose response for activation of tyrosine kinase activity at $10^{-8} \mathrm{M}$, and $10^{-7}$ $M$ as well as insulin binding curves.

Protein determinations. Proteins were determined with the Bio-Rad assay modified for the amounts of Triton X-100 present. The protein concentrations of the solubilized red cell ghosts were $1-3 \mathrm{mg} / \mathrm{ml}$. The ricin II-purified material had protein concentrations of 50-150 $\mu \mathrm{g} / \mathrm{ml}$.

Data analysis. Data were compared by Wilcoxon rank sum test except for comparison of regression lines, for which $t$ tests were used.

\section{Results}

Correlation of insulin-stimulated tyrosine kinase activity and specific insulin binding for Ricin II-purified solubilized erythrocyte preparations. The tyrosine kinase activity stimulated by $10^{-7} \mathrm{M}$ insulin over $15 \mathrm{~min}$ at room temperature and the specific ${ }^{125} \mathrm{I}$-insulin binding at $4^{\circ} \mathrm{C}$ of the ricin II-purified erythrocyte preparations were determined for 24 normal and 14 type II diabetic subjects. A linear correlation for tyrosine kinase activity and insulin binding was demonstrated for normal subjects, ( $r$ $=0.91, P<0.05)$ (Fig. $2 A$ ). The slope of this relationship was $92.7 \mathrm{pmol}{ }^{32} \mathrm{P}$ per $\mathrm{mg}$ polyGT per unit binding (bound over free $[B / F])$ per $15 \mathrm{~min}$. A strong correlation $(r=0.77)$ was also ob- 

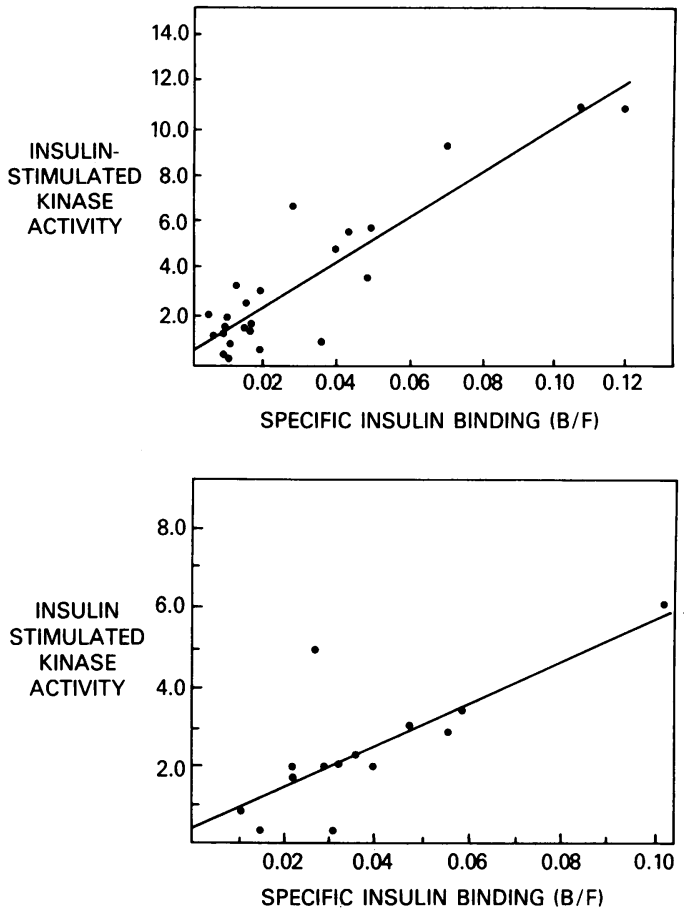

Figure 2. Insulin-stimulated tyrosine kinase activity as a linear function of specific insulin binding for ricin II-purified erythrocyte preparations from normal and type II diabetic subjects. $A$ displays data obtained from 24 normal subjects. The relationship between stimulated tyrosine kinase activity and insulin binding is in normal subjects linear (slope $=92.7 \mathrm{pmol}^{32} \mathrm{P} / \mathrm{mg}$ polyGT/unit $\mathrm{B} / \mathrm{F} / 15 \mathrm{~min}[\mathrm{r}=0.91]$ ). $B$ displays similar data obtained from 14 type II diabetic subjects (slope of $53.0 \mathrm{pmol}{ }^{32} \mathrm{P} / \mathrm{mg}$ polyGT $/ 15 \mathrm{~min} /$ unit $\mathrm{B} / \mathrm{F}[\mathrm{r}=0.77]$ ).

served for the relationship of tyrosine kinase and insulin binding for erythrocyte preparations from type II diabetics (Fig. $2 \mathrm{~B}$ ), the calculated slope of this correlation $\left(53.0 \mathrm{pmol}{ }^{32} \mathrm{P}\right.$ per $\mathrm{mg}$ polyGT per unit binding [B/F]) was reduced $42.8 \%$ compared with the slope calculated for normal subjects. Because the intercepts for each regression were not significantly different from 0 , the lines were recalculated to pass through the origin (Fig. 4 $A)$. The correlation coefficients for the lines passing through 0 are $\mathbf{0 . 9 6}$ for normals and $\mathbf{0 . 9 3}$ for diabetics. The average kinase activity per unit binding activity is $118 \pm 16$ for normals and $68 \pm 11$ for diabetics, as shown in Fig. $4 \mathrm{~B}$. In all three ways of expression (regression, regression through the origin, or average kinase-to-binding ratio), a significant difference is present in the relationship of kinase and binding activity when diabetics are compared with normals. The average kinase activities before and after correction for insulin binding are shown in Table III.

Similar studies were performed with IGF-1 as the ligand for binding and kinase activities. The correlations between binding and kinase activities were not as strong for IGF-1 as for insulin ( $r=0.55$ for normals, 0.69 for diabetics) and the slopes of the lines correlating binding and kinase activities $(b=0.098$ for normals, 0.15 for diabetics) were not statistically different $(P$ $=0.35$ ). The average kinase activities before and after correction for IGF-1 binding are shown in Table IV.

Binding studies. To detect possible selection bias in the purification of the erythrocyte receptors from the normal and untreated type II populations, intact erythrocyte and solubilized ricin II-purified insulin receptor ${ }^{125}$ I-insulin binding competition studies were performed. Although the average specific binding
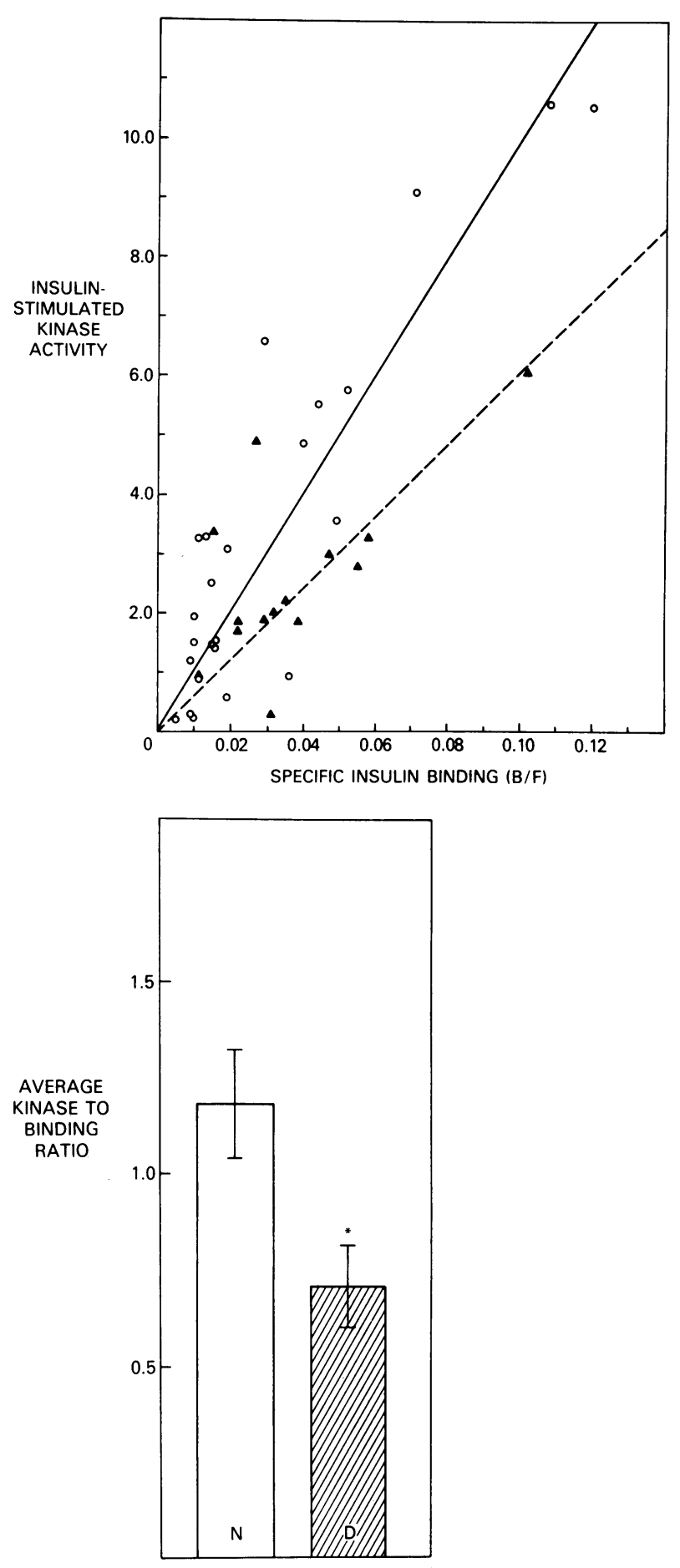

Figure 3. Comparison of data obtained from preparations from normals and diabetics. $A$ depicts the data for both normals and type II diabetics on the same axes used in Fig. 2, but the regression lines are now calculated to pass through the origin. The lines for normals (solid line, $\mathrm{m}=101.5, \mathrm{r}=0.96$ ) and diabetics (dashed line, $\mathrm{m}=60.7, \mathrm{r}$ $=0.93)$ are significantly different $(P=0.05)$. In $B$, the average kinaseto-binding ratio for each group is shown. The kinase-to-binding ratio for normals $(118 \pm 16$, open bar $N)$ is significantly greater than the ratio for diabetics $(68 \pm 11$, hatched bar $D) * P<0.05$. (All data expressed in arbitrary units \pm SEM.)

(B/F) of ${ }^{125}$ I-insulin per $10^{9} \mathrm{M}$ erythrocytes was slightly greater in the normal subjects than in the type II diabetic subjects $\mathbf{0 . 0 8 9}$ vs. 0.069 ), this difference was not statistically significant. Nor- 


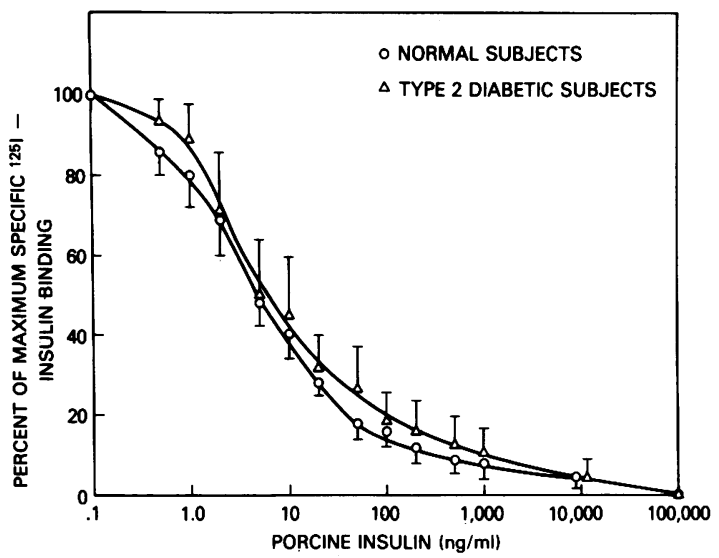

Figure 4. Insulin binding competition studies. $A$ shows the results of insulin binding competition (tracer ${ }^{125} \mathrm{I}$-insulin concentration $=0.1 \mathrm{ng} / \mathrm{ml}$ ) with porcine insulin for intact erythrocytes from 9 diabetic and 10 normal subjects, as described in Methods. The data are normalized to $100 \%$ specific insulin binding and reveal no significant differences between the competition curves from either group of subjects. Similar binding studies performed with solubilized ricin II-purified preparations from 14 normal and 10 type II diabetic subjects as described in Methods are shown in $B$ (tracer ${ }^{125}$ I-insulin concentration $=0.1 \mathrm{ng} / \mathrm{ml}$ ) and also show no differences between these two groups of subjects. Standard deviations are shown.

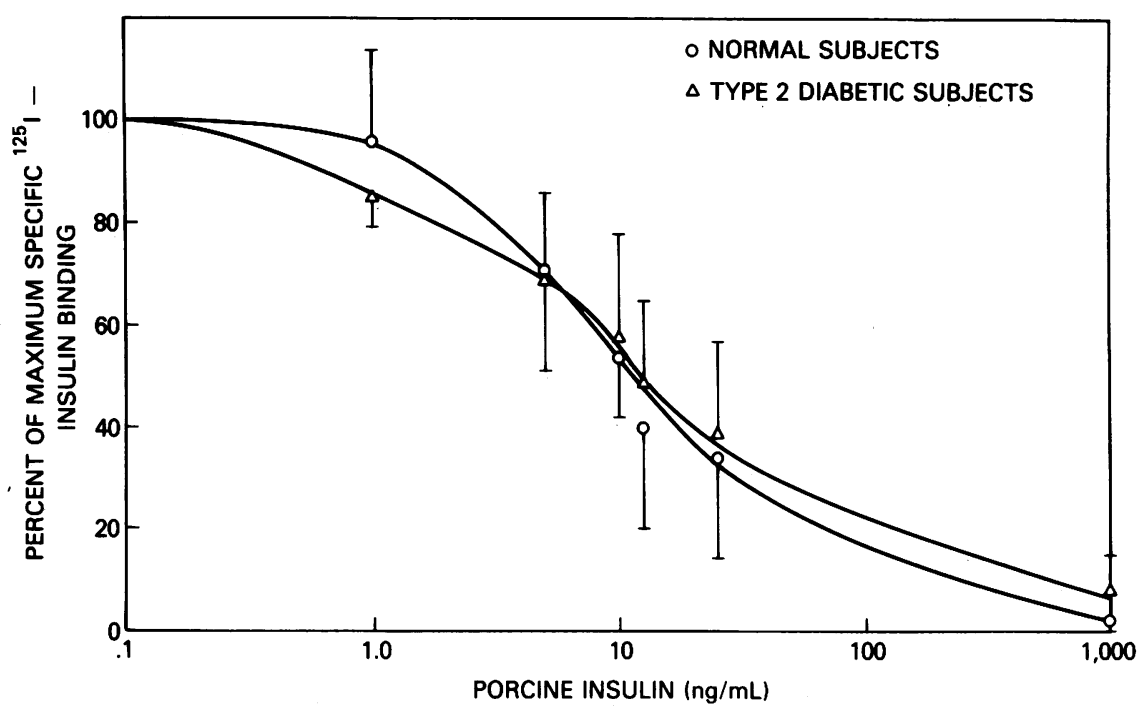

malization of the binding data to $100 \%$ specific binding permitted direct comparison of the competition curves. No significant differences in the shapes of the curves was noted (Fig. $4 \mathrm{~A}$ ), suggesting comparable insulin-binding affinity. Similar results were obtained for studies comparing the solubilized ricin II-purified preparations in these two groups. The average specific binding of ${ }^{125}$ I-insulin was slightly different $(B / F=0.031$ for normal and 0.032 for type II diabetic subjects) but the insulin binding competition curves were comparable (Fig. $4 \mathrm{~B}$ ).

Competition inhibition studies of ricin II-purified material from normal subjects with insulin analogues showed insulinbinding affinities for chicken insulin and proinsulin typical of the human insulin receptor (Fig. 5). The affinity of the ricin- purified material was five times greater for chicken insulin and 90 times less for proinsulin than for porcine insulin.

Competition binding studies in which ${ }^{125} \mathrm{I}$-labeled insulin was competed by unlabeled IGF-1 and ${ }^{125}$ I-labeled IGF-1 was competed by unlabeled insulin yielded results consistent with the presence of both insulin and IGF-1 receptors in these preparations (Fig. 6).

Insulin-stimulated autophosphorylation of the insulin receptor. Fig. 7 shows the insulin stimulation of the phosphorylation of the immunoprecipitated $\beta$ subunit of the insulin receptor $\left(M_{\mathrm{r}}\right.$ $.95 \mathrm{kD}$ ) in a sample before and after ricin II purification. The stimulation of autophosphorylation of the $\beta$ subunit by insulin is more clearly seen in the ricin II-purified material due to the

Table III. Insulin Binding and Insulin-stimulated Tyrosine Kinase Activities

\begin{tabular}{|c|c|c|c|c|c|}
\hline Group & $\begin{array}{l}\text { Specific insulin } \\
\text { binding }\end{array}$ & $\begin{array}{l}\text { Kinase activity* } \\
\text { without insulin }\end{array}$ & $\begin{array}{l}\text { Kinase activity* } \\
\text { with } 10^{-7} \mathrm{M} \\
\text { insulin }\end{array}$ & $\begin{array}{l}\text { Insulin stimulated } \\
\text { kinase activity* }\end{array}$ & $\begin{array}{l}\text { Average stimulated kinase activity/ } \\
\text { average specific binding }\end{array}$ \\
\hline & $B / F$ & & & & \\
\hline Normals $(n=24)$ & $0.031 \pm 0.006$ & $5.67 \pm 1.98$ & $9.08 \pm 1.83$ & $3.41 \pm 0.67$ & $111.0 \pm 13.66$ \\
\hline Type II diabetes $(n=14)$ & $0.032 \pm 0.006$ & $4.44 \pm 0.99$ & $6.80 \pm 1.37$ & $2.36 \pm 0.43$ & $73.75 \pm 11.29^{\ddagger}$ \\
\hline Obese normals & $0.017 \pm 0.003$ & $3.95 \pm 1.27$ & $7.50 \pm 1.63$ & $3.55 \pm 0.65$ & $208.82 \pm 127.5$ \\
\hline
\end{tabular}

All data shown \pm SEM. $\quad *$ (pmol ${ }^{32} \mathrm{P} / \mathrm{mg}$ polyGT). ${ }^{\ddagger}$ Lower than ratio for normals, $P<0.05$. There is no significant difference between groups for other data listed. 


\begin{tabular}{llllll}
\hline Group & Specific IGF-1 binding & $\begin{array}{l}\text { Kinase activity* } \\
\text { without IGF-1 }\end{array}$ & $\begin{array}{l}\text { Kinase activity* } \\
\text { with } 10^{-8} \mathrm{M} \\
\text { IGF-1 }\end{array}$ & $\begin{array}{l}\text { IGF-1 stimulated } \\
\text { kinase activity* }\end{array}$ & $\begin{array}{l}\text { Average stimulated kinase activity/ } \\
\text { average specific binding }\end{array}$ \\
\hline & $B / F$ & & & & \\
Normals $(n=10)$ & $0.12 \pm 0.18$ & $1.77 \pm 0.31^{\ddagger}$ & $3.18 \pm 0.47$ & $1.40 \pm 0.32$ & $11.77 \pm 2.28$ \\
Type II diabetes $(n=7)$ & $0.14 \pm 0.28$ & $2.41 \pm 0.77$ & $4.73 \pm 1.10$ & $2.32 \pm 0.64$ & $16.57 \pm 3.35^{\S}$ \\
\hline
\end{tabular}

All data shown \pm SEM. * ${ }^{*}$ pmol ${ }^{32} \mathrm{P} / \mathrm{mg}$ polyGT. ${ }^{\ddagger}$ These assays were performed on different fractions containing less insulin-binding and kinase activities than the fractions used in Table III. However, for each patient, each fraction from the ricin II column has the same stimulated kinase/ specific-binding activities ratio. 'The activities ratio is not significantly different $(P>0.05)$.

removal of nonstimulated phosphoproteins and a general decrease in retained background radioactivity. Only one major phosphoprotein band is observed in ricin II-purified material immunoprecipitated with anti-insulin receptor antibody.

Comparison of insulin-stimulated tyrosine kinase activity and binding activity under identical conditions. The average insulin binding results (B/F) for ricin II preparations studied at room temperature ( $n=5$ in each group) were $0.0052 \pm 0.0006$ for normals and $0.0083 \pm 0.0013$ for diabetics. The average tyrosine kinase activities stimulated by insulin were $1.16 \pm 0.15$ for normals and $0.87 \pm 0.29$ for diabetics at $10^{-7} \mathrm{M}$ insulin, and $1.20 \pm 0.22$ for normals and $1.00 \pm 0.24$ for diabetics at $10^{-8} \mathrm{M}$ insulin (in picomoles ${ }^{32} \mathrm{P}$ per $\mathrm{mg}$ polyGT per $15 \mathrm{~min}$ ). Fig. 8 shows these results in average kinase activity per unit binding $\times 10^{-2}$. The data indicate a significant decrease in tyrosine kinase activity stimulated by insulin per unit of insulin binding in diabetics compared with normals under these conditions using $10^{-7} \mathrm{M}$ insulin as the stimulatory ligand concentration (240.0 \pm 50.0 for normals vs. $145.0 \pm 50.0$ for diabetics, a $37.5 \%$ reduction). Moreover, a similar decrease was also observed with $10^{-8} \mathrm{M}$ insulin as the stimulatory ligand concentration.

\section{Discussion}

We have described methods for partial purification of human erythrocyte insulin receptors and quantitative comparisons of

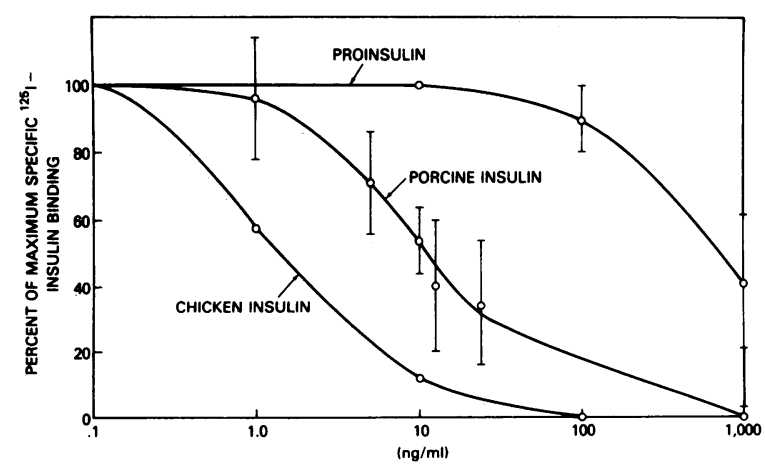

Figure 5. Insulin binding inhibition studies with insulin analogues for ricin II-purified erythrocyte insulin receptors from normal subjects. Insulin binding was performed at $4^{\circ} \mathrm{C}$ for $24 \mathrm{~h}$ in the presence of PMSF as described in Methods. ${ }^{125} \mathrm{I}$-porcine insulin $(0.1 \mathrm{ng} / \mathrm{ml})$ was displaced $50 \%$ at concentration of $1.4 \mathrm{ng} / \mathrm{ml}$ of chicken insulin $(n$ $=1), 12 \mathrm{ng} / \mathrm{ml}$ of porcine insulin $(n=14)$, and $700 \mathrm{ng} / \mathrm{ml}$ of proinsulin $(n=2)$ for ricin II-purified erythrocyte insulin receptors. Standard deviations are shown. the biochemical properties of these preparations from two different groups. One major finding of this study is the demonstration of a correlation between binding ( $\alpha$ subunit function) and tyrosine kinase activities ( $\beta$ subunit function) of solubilized erythrocyte insulin and IGF-1 receptors from normal subjects. We define the slope of the line describing this correlation for each ligand as "coupling" between the $\alpha$ and $\beta$ subunits. The other major finding is a statistically significant difference in the slopes in the lines of correlation between insulin related $\alpha$ and $\beta$ subunit functions of the normals and untreated type II diabetics. We define this as altered coupling with respect to insulin between the $\alpha$ and $\beta$ subunit function of the untreated type II diabetic as compared with the normal.

In standardizing our data the specific binding was positively correlated with the kinase activity of the preparations in the absence $(r=0.77)$ and the presence of insulin $(r=0.85)$ but was best correlated with the actual kinase activity stimulated by insulin $(r=0.91)$. There was little correlation of binding activity and protein concentration.

The $\mathrm{B} / \mathrm{F}$ ratio for insulin binding is theoretically proportional to the number of receptors present for a given set of conditions. The use of $B / F$ as a means to standardize the comparison of data is supported by the similarity of the binding curves of the

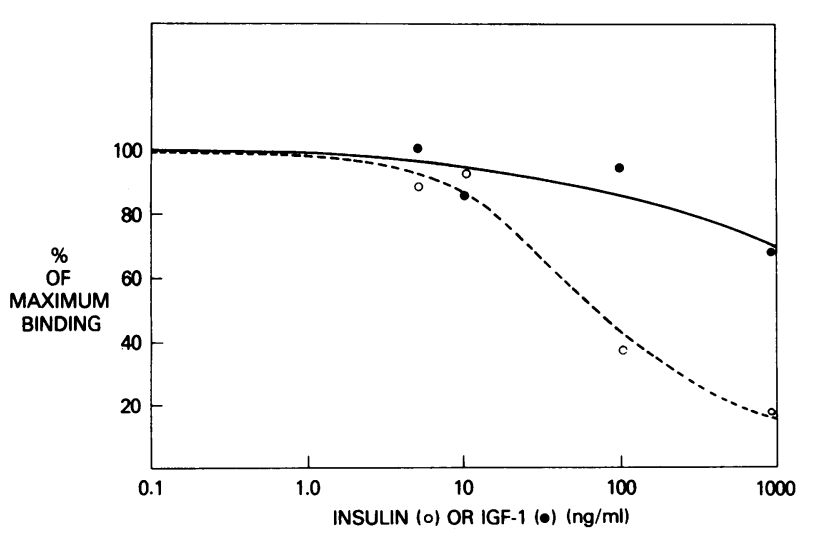

Figure 6. Heterologous ligand binding competition curves for ricin IIpurified preparations. Study of ${ }^{125} \mathrm{I}$-labeled insulin $(0.1 \mathrm{ng} / \mathrm{ml})$ in the presence of increasing amounts of unlabeled IGF-1 showed little evidence of competitive displacement until $>100 \mathrm{ng} / \mathrm{ml}$ of IGF-1 was present (closed circles). Study of ${ }^{125}$ I-labeled IGF-1 $(0.1 \mathrm{ng} / \mathrm{ml})$ in the presence of increasing amounts of unlabeled insulin showed displacement with an $\mathrm{IC}_{50}$ of $62 \mathrm{ng} / \mathrm{ml}$, whereas insulin completes for ${ }^{125} \mathrm{I}$-insulin with an $\mathrm{IC}_{50}$ of $10 \mathrm{ng} / \mathrm{ml}$. These studies indicate that each type of receptor, IGF-1 and insulin, are present in these preparations. 


\begin{tabular}{|c|c|c|}
\hline Ricin II Purified & ++ & -- \\
\hline Insulin, 10-7M & +- & +- \\
\hline
\end{tabular}

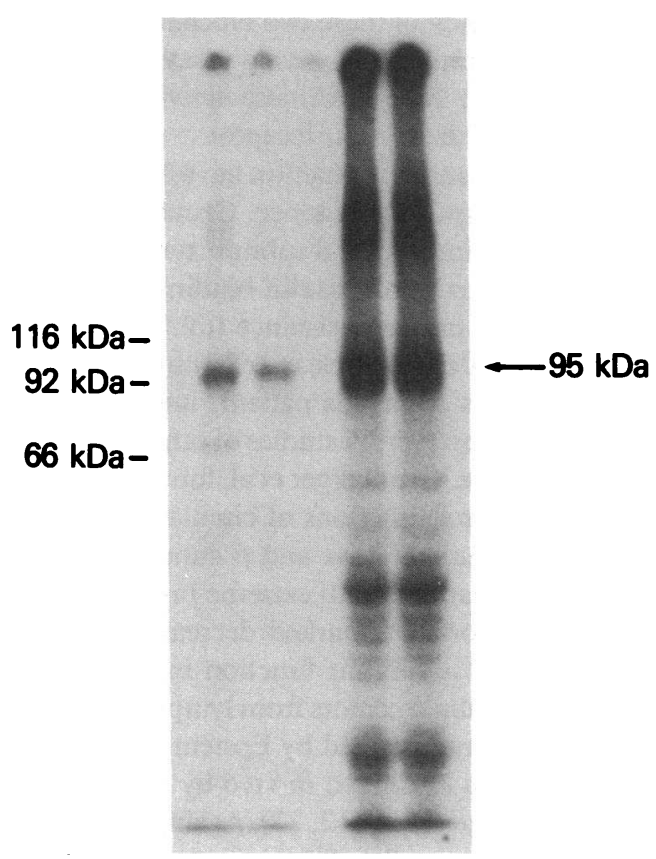

Figure 7. Insulin-stimulated autophosphorylation of the $\beta$ subunit of erythrocyte insulin receptors before and after ricin II affinity chromatography. Autophosphorylation and immunoprecipitation were performed as described in Methods. All lanes show a major phosphoprotein at $M_{\mathrm{r}} 95 \mathrm{kD}$ consistent with the $\beta$ subunit of the insulin receptor. Ricin II purification before the autophosphorylation experiment results in the removal of several nonspecific phosphoproteins and more clearly observed stimulation of autophosphorylation by $10^{-7} \mathrm{M}$ insulin.

ricin II-purified preparations from all subjects. Nonetheless, it is the correlation of insulin binding and insulin-stimulated kinase activities itself rather than the absolute kinase activity per unit binding activity that allows comparison of the two patient groups.

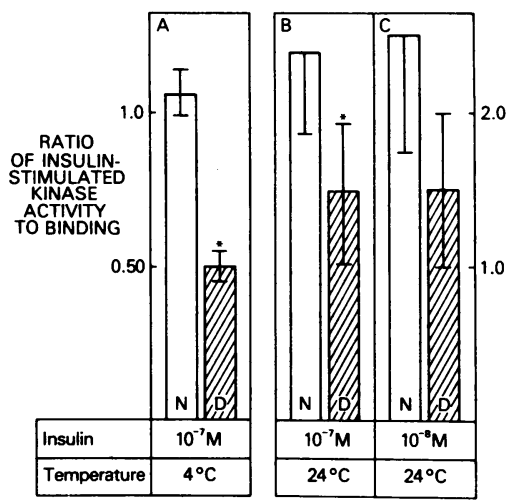

Figure 8. Comparison of the averaged ratios of insulin-stimulated tyrosine kinase activity and specific insulin binding under varying conditions. Averaged data from five normal and five untreated type II diabetios are shown. Tyrosine kinase activity in all experiments was measured at $24^{\circ} \mathrm{C}$ and insulin binding at $4^{\circ} \mathrm{C}(A)$ or $24^{\circ} \mathrm{C}(B$ and $C)$. Kinase activity was stimulated

by $10^{-7} \mathrm{M}(A$ and $B)$ or $10^{-8} \mathrm{M}$ insulin $(C)$ as indicated. The ratio for diabetics (hatched bar $D$ ) is significantly lower than the ratio for normals (open bar $N$ ). ${ }^{*} P=0.05$. (The ratio values are shown on the $y$ axis $\left.\times 10^{-2}\right)$.
For examination of data from individuals or small numbers of patients, the kinase activity per unit binding is a convenient approximation of the correlation (Tables III and IV).

Our type II diabetic patients were untreated at the time of study and differed from the normals in at least three obvious ways: they were hyperglycemic, had a greater average weight, and were somewhat older (Table I). Examination of the subset of normal and obese individuals who were older than $45 \mathrm{yr}$ at the time of study did not show a significant difference from normals in six out of seven cases. Examination of a separate group of obese normal subjects (Tables I and III) also revealed no difference in the coupling of insulin binding and insulinstimulated kinase activities from normal weight subjects. There was no difference in data obtained from male or female subjects. We conclude that the differences observed between normal and diabetic subjects are not explained by differences in age or weight.

The insulin receptors of erythrocytes have been shown to be qualitatively similar to receptors of other cell types (10). Because mature erythrocytes are anucleate and incapable of protein synthesis, they are less responsive to physiologic manipulations of insulin, as assessed by intact red cell insulin binding $(14,15)$. The biochemical functions of the $\alpha$ and $\beta$ subunits appear to be similar to those of insulin receptors from other cell types (6). Intact cell binding studies for a given individual, however, give similar results to those obtained from mononuclear blood cells $(15,16)$. Erythrocytes have been shown to express fewer insulin receptors on the cell surface with advancing cell age (17). All subjects in this study had normal hematocrit and reticulocyte counts, suggesting normal red cell age distributions. The insulin binding of preparations isolated from normal subjects or diabetics were not significantly different (Table III).

IGF-1 receptors on red blood cells have recently been characterized $(18,19)$. Our preparations after ricin II purification contain both insulin and IGF-1 receptors as characterized by binding studies (Figs. 5 and 6) and specific immunoprecipitation of the insulin receptor $\beta$ subunit by low titers $(1: 100)$ of antiinsulin receptor polyclonal antibodies (Fig. 7). The dose of insulin used in this study, $10^{-7} \mathrm{M}$, has been reported to cause submaximal stimulation of solubilized lectin-purified IGF-1 receptor kinase activity towards polyGT under experimental conditions similar to those used in our study $(20,21)$. However, when we added maximally stimulating doses of insulin to erythrocyte receptor preparations along with maximally stimulated doses of IGF-1, no significant increase in kinase activity was observed. These results suggest that $10^{-7} \mathrm{M}$ insulin or $10^{-8} \mathrm{M}$ IGF-1 stimulate maximal activity from both populations of receptors in each preparation. Although kinase activity and the $\mathrm{B} / \mathrm{F}$ ratio for IGF-1 binding were correlated, this correlation was not different between normal and diabetic subjects. In fact, the slope of this correlation defining coupling for IGF-1 was greater for diabetics than normals, although not to a significant degree. This trend is opposite that found for insulin. Though our ricin II-purified preparations contain both insulin and IGF-1 binding sites, the difference in the slopes of the relationship between binding and stimulated protein kinase activity is seen only when expressed in terms of insulin binding. Moreover, a similar difference between the normal and diabetic populations was observed using $10^{-8} \mathrm{M}$ insulin as the stimulatory ligand concentration (Fig. 8). This observation also suggests that the insulin receptors are responsible for most of the differences seen, because the IGF-1 receptor kinase is less activated at this concentration of insulin (20). 
Solubilized erythrocyte membrane preparations before and after ricin II-purification have similar insulin binding competition curves (data not shown). There was no difference in the percent binding activity retained by the ricin II lectin between normal and type II diabetic patients. We cannot exclude a selection bias in our data introduced by the use of lectin purification, but we feel that this is minimal because $>60 \%$ of the binding activity was retained in all instances and all samples received identical treatment.

Lectin agarose beads have proved a useful tool in the purification and concentration of membrane glycoproteins and glycolipids (9). The insulin receptors of most cell types can be quantitatively recovered after adsorption to wheat germ agglutinin agarose beads (11). The erythrocyte insulin receptor is not efficiently recovered using the wheat germ lectin but is satisfactorily recovered using ricin II (Table II). The specificity of lectin binding is complex, involving recognition of individual residues, specific glycosidic linkages or oligosaccharide groups (22). In general, wheat germ agglutinin binds to sialic acid residues, while ricin II binds to mannose residues. The erythrocyte insulin receptors may be poorly retained by wheat germ agglutinin due to failure to adhere or failure to compete with more heavily sialated components of the red cell membrane (i.e., glycophorin). In a preliminary experiment to examine this issue, serial passage of solubilized red cell membranes over sequential wheat germ agglutinin agarose beads failed to improve retention of insulin binding activity, suggesting that the poor adherence of these receptors per se results in poor retention (data not shown, R. J. Comi). The red cell insulin receptor may be desialated, although removal of sialic acid residues by neuraminidase treatment of the $\alpha$ subunit of these receptors can be demonstrated (23).

Ricin II purification of solubilized red cell membranes results in at least a 10-fold purification and concentration of binding activity. In Fig. 7, ricin II-purified preparations show a decrease in background retention of radioactive label and removal of several nonspecific phosphoproteins. Insulin degrading activity of these preparations is significantly reduced compared with solubilized preparations without ricin II purification. In the absence of ricin II purification, assays of kinase activity with polyGT were found to have enormous background activities and inconsistent stimulation of the kinase activity by insulin. For these reasons, ricin II purification significantly facilitates the study of these receptors.

The conditions chosen for this study, binding at $4{ }^{\circ} \mathrm{C}$ and kinase activity elevated by $10^{-7} \mathrm{M}$ insulin, were selected to allow maximum accuracy and reproducibility. Although a similar difference between preparations from normal and diabetic groups could be shown under identical buffer and temperature conditions (Fig. 8) and also at lower more specific insulin concentrations $\left(10^{-8} \mathrm{M}\right.$ rather than $\left.10^{-7} \mathrm{M}\right)$, there is a greater degree of nonspecific binding at the higher temperature and a lesser stimulation of kinase activity over basal activity with more prolonged preincubation. Thus, we prefer standard well-characterized assays to allow the most reliable correlation of binding and kinase activities.

The use of the substrate polyGT to measure tyrosine kinase activity has many advantages over measurement of autophosphorylation of the $\beta$ subunit as a measure of the kinase function of the insulin receptor $(12,13,24,25)$. Phosphorylation of the tyrosine residues of an external substrate separates the tyrosine kinase activity of the insulin receptor from its function as a substrate. Because the insulin-binding activity of the insulin receptors is measured separately, the correlation of tyrosine kinase activity stimulated by insulin and specific insulin-binding activity is a measure of the coupling of these two biochemical functions of the insulin-binding receptors. However, assays using polyGT cannot distinguish IGF-1 receptor kinase activities stimulated by insulin from those of the insulin receptor.

Previous studies of $\beta$ subunit function have concentrated on individuals with severe insulin resistance. Grunberger et al. described a marked reduction in the $\beta$ subunit tyrosine kinase of a patient with normal $\alpha$ subunit insulin binding who had type A syndrome of extreme insulin resistance (6). This defect was described for circulating mononuclear cells but has also been found in other cell types from this patient, including red cell insulin receptors (26). However, in studies of other patients with extreme insulin resistance, Grunberger et al. found parallel diminution of $\alpha$ and $\beta$ subunit functions of circulating monocytes (12). Thus, defective coupling of $\alpha$ and $\beta$ subunit function is not characteristic of all patients with extreme insulin resistance. Grigorescu has also reported a marked decrease in $\beta$ subunit function compared with $\alpha$ subunit function in a patient with type A syndrome (5). Insulin receptors from lymphocytes isolated from patients and then transformed by Epstein-Barr virus cultured cell lines have been examined in vivo by Whittaker et al. and in vitro by Grunberger et al. $(12,27)$. Again, diminution of $\beta$ subunit kinase function paralleled diminution in insulin binding in these two circumstances in patients with extreme insulin resistance.

There have been three recent studies of quantitative changes in the tyrosine kinase activity of insulin receptors. LeMarchandBrustel et al. described an interesting animal model of acquired insulin resistance and diabetes in chemically induced hyperphagic mice in which diminished $\beta$ subunit kinase activity of skeletal muscle cell insulin receptors per unit binding per milligram was found for both autophosphorylation and kinase activity towards polyGT (28). This defect developed gradually after induction of the hyperphagic state and parallel with the development of obesity. This work suggests that diminished coupling of $\alpha$ and $\beta$ subunit function may be acquired. Further studies of type II diabetic patients, whose disease has both genetic and acquired components and who also show defective $\alpha$ and $\beta$ subunit coupling, may reveal similar findings. Arsenis and Livingston reported diminution of insulin receptor tyrosine kinase activity in rat adipocytes exposed in vitro to high concentrations of insulin (29). This study demonstrated a $40 \%$ reduction in the insulin-stimulated tyrosine kinase activity maximum velocity toward polyGT when expressed per unit of insulin binding. This study is particularly relevant to type II diabetes, because hyperinsulinemia has been described in some of these patients along with a decrease in the binding of circulating cells. In our patient groups, however, hyperinsulinism and decreased insulin binding to circulating cells were not present. These studies indicate the possibility of acquired quantitative changes in insulin receptor tyrosine kinase activity, which may be present in our diabetic patients.

Since the original submission of this manuscript, Caro et al. demonstrated a quantitative decrease in kinase activity per unit binding in freshly isolated hepatocytes from morbidly obese type II diabetics as compared with similarly obese nondiabetics (30). 
Our findings in erythrocyte receptors from diabetics and normals of lesser degrees of obesity are comparable to these results obtained from a major metabolic organ. Also, Friedenberg et al. have reported very similar results in freshly isolated human adipocyte insulin receptors (31). These studies support the finding of diminished kinase activity per unit binding in type II diabetics found in our study and also support the use of insulin receptors from circulating cells in studies of metabolic diseases.

Finally, the significance of these findings with respect to insulin action or insulin resistance is unknown. Whereas it is clear that insulin binding is required for insulin action, the role of receptor phosphorylation remains unclear. Whether phosphorylation is an integral part of transduction for certain functions or it occurs parallel with transduction is unknown $(30,32,33)$. More recently, it has been shown that there are differences in the phosphorylation patterns of cell-free and intact cell systems (34). The significance of these findings remains obscure. Unfortunately, our data do not help clarify these important questions.

Overall, we have described a new method for the isolation of reasonable quantities of partially purified human erythrocyte growth factor receptors and a system of standardized assays to study the biochemical properties of these receptors. Comparison of normal and type II diabetic populations with these methods has revealed an intriguing difference in the coupling of insulinstimulated tyrosine kinase and insulin-binding activities in preparations from these two groups.

\section{Acknowledgments}

The authors thank Linda Fitzgerald and Jill Waalen for their technical assistance.

\section{References}

1. Roth, J., and C. Grunfeld. 1985. Mechanism of action of peptide hormones and catecholamines. In Williams Textbook of Endocrinology. J. Wilson and D. Foster, editors. W. B. Saunders Co., Philadelphia, Seventh Ed. 76-122.

2. Ullrich, A., J. R. Bell, E. Y. Chen. R. Herrera, L. M. Petruzzelli, T. J. Dull, A. Gray, L. Coussens, Y.-C. Liao, M. Tsubokawa, A. Mason, P. H. Seeburg, C. Grunfeld, O. M. Rosen, and J. Ramachandran. 1985. Human insulin receptor and its relationship to the tyrosine kinase family of oncogenes. Nature (Lond.). 313:756-761.

3. Ebina, Y., L. Ellis, K. Jarnaghin, M. Edery, L. Graf, E. Clauser, J. Ou, F. Masiarz, Y. W. Kan, I. D. Goldfine, R. A. Roth, and W. J. Rutter. 1985. The human insulin receptor cDNA: the structural basis for hormone activated transmembrane signalling. Cell. 40:747-758.

4. Kasuga, M., F. A. Karlsson, and C. R. Kahn. 1982. Insulin stimulates the phosphorylation of the 95,000 dalton subunit of its own receptor. Science (Wash. DC). 215:185-187.

5. Hedo, J. A., and I. A. Simpson. 1984. Internalization of insulin receptors in the isolated rat adipose cell. Demonstration of the vectorial disposition of receptor subunits. J. Biol. Chem. 259:11083-11089.

6. Grunberger, G., Y. Zick, and P. Gorden. 1984. Defect in phosphorylation of insulin receptors in cells from an insulin resistant patient with normal insulin binding. Science (Wash. DC). 223:932-934.

7. Grigorescu, F., J. S. Flier, and C. R. Kahn. 1984. Defect in insulin receptor phosphorylation in erythrocytes and fibroblasts associated with severe insulin resistance. J. Biol. Chem. 259:15003-15006.

8. Grigorescu, F., M. F. White, and C. R. Kahn. 1983. Insulin binding and insulin dependent phosphorylation of the insulin receptor solubilized from human erythrocytes. J. Biol. Chem. 258:13708-13715.

9. Hedo, J. A. 1984. Lectins as tools for the purification of membrane receptors. In Receptor Purification Procedures. J. C. Venter and L. C. Harrison, editors. Alan R. Liss, Inc., New York. 45-60.

10. Ghambir, K. K., J. A. Archer, and L. Carter. 1977. Insulin radioreceptor assay for human erythrocytes. Clin. Chem. 23:1590-1595.

11. Hedo, J. A., L. C. Harrison, and J. Roth. 1981. Binding of insulin receptors to lectins: evidence for common carbohydrate determinants on several membrane receptors. Biochemistry. 20:3385-3393.

12. Grunberger, G., R. J. Comi, S. I. Taylor, and P. Gorden. 1984. Tyrosine kinase activity of the insulin receptor of patients with Type A extreme insulin resistance: studies with circulating mononuclear cells, and cultured lymphocytes. J. Clin. Endocrinol. \& Metab. 59:1152-1158.

13. Grunberger, G., Y. Zick, J. Roth, and P. Gorden. 1983. Protein kinase activity of the insulin receptor in human circulating and cultured mononuclear cells. Biochem. Biophys. Res. Commun. 115:560-566.

14. De Pirro, R., A. Fusco, R. Lauro, I. Testa, G. Ferretti, and C. De Martinis. 1980. Insulin receptors on monocytes and erythrocytes from obese patients. J. Clin. Endocrinol. \& Metab. 51:1437-1440.

15. Wachslicht-Rodbard, H., H. A. Gross, D. Rodbard, M. H. Ebert, and J. Roth. 1976. Increased insulin binding to erythrocytes in anorexia nervosa. N. Engl. J. Med. 300:882-887.

16. Dons, R. F., J. Ryan, P. Gorden, and H. Wachslicht-Rodbard. 1981. Erythrocyte and monocyte insulin binding in man. A comparative analysis in normal and disease states. Diabetes. 30:896-902.

17. Dons, R. F., L. M. Corash, and P. Gorden. 1981. The insulin receptor is an age-dependent component of the human erythrocyte membrane. J. Biol. Chem. 256:2982-2987.

18. Hizuka, N., K. Takano, I. Tanaka, N. Honda, T. Tsushima, and K. Shizume. 1985. Characterization of insulin-like growth factor I receptor on human erythrocytes. J. Clin. Endocrinol. \& Metab. 61:1066-1070.

19. Catanese, V. M., F. Grigorescu, G. L. King, and C. R. Kahn. 1985. Demonstration of an active IGF-1 receptor kinase on human erythrocytes. Clin. Res. 33:306A. (Abstr.)

20. Zick, Y., N. Sasaki, R. W. Rees-Jones, G. Grunberger, S. P. Nissley, and M. M. Rechler. 1984. Insulin-like growth factor I (IGF-1) stimulates tyrosine kinase activity in purified receptors from a rat liver cell line. Biochem. Biophys. Res. Commun. 119:6-13.

21. Jacobs, S., F. C. Kull, Jr., H. S. Earp, M. E. Svoboda, J. J. Van Wyk, and P. Cuatrecasas. 1983. Somatomedin-C stimulates the phosphorylation of the $\beta$-subunit of its own receptor. J. Biol. Chem. 258: 9581-9584.

22. Goldstein, I. J., and C. E. Hayes. 1978. The lectins: carbohydrate binding proteins of plants and animals. Adv. Carbohydr. Chem. Biochem. 35:127-340.

23. McElduff, A., R. J. Comi, and G. Grunberger. 1985. Structural difference of the insulin receptors from circulating monocytes and erythrocytes. Biochem. Biophys. Res. Commun. 133:1175-1180.

24. Braun, S., W. E. Raymond, and E. Racker. 1984. Synthetic tyrosine polymers as substrates and inhibitors of tyrosine specific protein kinases. J. Biol. Chem. 259:2051-2054.

25. Zick, Y., G. Grunberger, R. W. Rees-Jones, and R. J. Comi. 1985. Use of tyrosine-containing copolymers to characterize the substrate specificity of insulin and other hormone-stimulated tyrosine kinases. Eur. J. Biochem. 148:177-182.

26. Grunberger, G., A. McElduff, R. J. Comi, J. M. Podskalny, S. I. Taylor, and P. Gorden. 1985. Type A insulin resistance and defective tyrosine kinase activity: normal kinase expression in virally transformed cells. Clin. Res. 33:614A. (Abstr.)

27. Whittaker, J., Y. Zick, J. Roth, and S. I. Taylor. 1985. Insulin stimulated receptor phosphorylation appears normal in cultured EpsteinBarr virus-transformed lymphocyte cell lines derived from patients with extreme insulin resistance. J. Clin. Endocrinol. \& Metab. 60:381-386.

28. LeMarchand-Brustel, Y., T. Gremeaux, R. Balloth, and E. Van 
Obberghen. 1985. Insulin receptor tyrosine kinase is defective skeletal muscle of insulin-resistant obese mice. Nature (Lond.). 315:676-679.

29. Arsenis, G., and J. N. Livingston. 1986. Alterations in the tyrosine kinase activity of the insulin receptor produced by in vitro hyperinsulinemia. J. Biol. Chem. 261:147-153.

30. Caro, J. F., O. Hoop, W. J. Pories, D. Meelheim, E. G. Fickinger, F. Thomas, M. Jenguin, J. F. Silverman, P. G. Khazanie, and M. K. Sinha. 1986. Studies on the mechanism of insulin resistance in the liver from humans with noninsulin-dependent diabetes. J. Clin. Invest. 78: 249-258.

31. Freidenberg, G. R., R. R. Henry, H. H. Klein, and J. M. Olefsky.
1986. Insulin receptor tyrosine kinase activity is reduced in NIDDM. Diabetes. 35(Suppl. 1):9A, (Abstr.)

32. Simpson, I. A., and J. A. Hedo. 1984. Insulin receptor phosphorylation may not be a prerequisite for acute insulin action. Science (Wash. DC). 223:1301-1304.

33. Zick, Y., R. W. Rees-Jones, S. I. Taylor, P. Gorden, and J. Roth. 1984. The role of antireceptor antibodies in stimulating phosphorylation of the insulin receptor. J. Biol. Chem. 259:4396-4400.

34. Kasuga, M., Y. Zick, D. L. Blithe, M. Crettaz, and C. R. Kahn. 1982. Insulin stimulates tyrosine phosphorylation of the insulin receptor in a cell free system. Nature (Lond.). 298:667-669. 